\title{
An Insight into Airline Dynamic Pricing Practices in Emerging Markets: Effects of Low Cost Carriers' Presence on Routes from Belgrade "Nikola Tesla" Airport
}

\author{
NIKOLA V. IVANOV, University of Belgrade, \\ Faculty of Transport and Traffic Engineering, Belgrade \\ Professional paper \\ UDC: 338.51 \\ RADOSAV B. JOVANOVIĆ, University of Belgrade, \\ 338.534:656.7 \\ Faculty of Transport and Traffic Engineering, Belgrade DOI: 10.5937/tehnika1601119I

\begin{abstract}
Dynamic pricing and revenue management in airline industry have been the subject of research for more than twenty years now. Building upon that massive body of research, in this paper we investigate actual dynamic pricing patterns in new and emerging markets. We specifically focus on the impact that recent entry of low cost carriers on a number of routes from Belgrade Nikola Tesla Airport might have had on pricing practices of legacy incumbents. Unlike with most of previous contributions in the field, we analyse the market characterised by relatively low frequencies and predominantly short-to-medium haul flights. In this paper, we observe and analyse pricing dynamics on two types of routes: routes where only legacy carriers operate and routes where legacy carriers face competition from low cost carriers. The effects of route competition on offered airline fares are estimated and conclusions derived.
\end{abstract}

Key words: dynamic pricing, airline competition, emerging market

\section{INTRODUCTION}

Dynamic pricing, being the core part of the concept of revenue management, is one of the main instruments at airlines' disposal to increase profit. In essence, it involves a set of pricing strategies aiming to maximize profit, and has been employed in a number of industries characterised by, inter alia, non-storable product, and fixed capacity [1]. In airline industry, the notion of dynamic pricing basically relates to changes in the level of ticket price for a given class of a given flight, throughout the 'booking' period, i.e. as day of departure approaches.

Dynamic pricing and revenue management in airline industry have been the subject of research for more than twenty years now. A number of different models were proposed in the literature taking account of different market settings, ranging between fully monopolistic and very competitive ones [2]. It is generally accepted in the literature that ticket prices for a given flight increase as day of departure approaches, but it is subject to debate if this increase is monotonous or follows a specific pattern [3].

Author's address: Nikola Ivanov, University of Belgrade, Faculty of Transport and Traffic Engineering, Belgrade, Vojvode Stepe 305

Paper received: 25.01.2016.

Paper accepted: 01.02.2016.
Previous contributions on pricing dynamics targeted well-established and mature markets, usually including routes with high competition and frequency [4]. Building upon that massive body of research, we investigate actual dynamic pricing patterns in new and emerging markets. Unlike with most of previous contributions in the field, we analyse the market characterised by relatively low frequencies and predominantly short-to-medium haul flights. This is quite a typical landscape in a number of Central and Eastern European countries, including e.g. airports Bratislava, Belgrade, Skopje, Sofia, Timisoara, Tirana, Zagreb, etc. As an illustrative case study, we specifically focus on the impact that recent entry of low cost carriers (LCC) on a number of routes from Belgrade Nikola Tesla Airport (hereinafter referred to as BEG) might have had on pricing practices of full-service carriers (FSC) incumbents.

In this paper, we focus on temporal evolution of prices, i.e. how the ticket price, as seen by a passenger, changes during several weeks before the flight in seemingly different competitive settings. In other wor$\mathrm{ds}$, we test if the presence of route competition affects pricing dynamics, using routes without competition as benchmark. More specifically, we address the following research questions:

- Are prices lower on competitive routes compared to routes with FSC service only? 
- Do prices on routes with vs. without competition follow a notably different pattern (temporal evolution)?

- Is there any 'correlation' between competitors' prices on the same route (in terms of temporal evolution)?

The reminder of the paper is structured as follows. Section 2 describes the data and data collection process. Data analysis and relevant results are presented in Section 3. Conclusions and discussion concludes the paper (Section 4).

\section{DATA}

Recent studies used various data sources: publicly available data (USA Department of Transport, UK CAA), travel agents' and online data. We have collected ticket price data directly from airlines' websites, since online services like Opodo or Travelocity do not necessarily reveal discounts offered by airlines [3].

Flights under consideration depart from BEG from March $31^{\text {st }}$ to April $2^{\text {nd }} 2014$ and return a week later, i.e. from April $7^{\text {th }}$ till $9^{\text {th }}$ 2014. The timeframe for the ticket prices in our dataset ranges from 50 days prior to departure up to the day before the departure date. The main reason for choosing a 7-day return flight is that LCCs from BEG did not offer necessary flight frequency suitable for business passengers. According to STATFOR Interactive Dashboard (SID) data [5], there were 10 times more operations carried by FSC compared to LCC incumbents in February and March 2014.

Due to low flying frequency (six flights a day on average, SID) it is not likely that LCCs would considerably compete for business travellers with FSC. On the other hand, it is more likely that LCCs compete with FSC for leisure passengers (mostly), hence the decision to check fares for a week long return flights has been made. Further, it was important to choose return flight before peak period (Easter) to have prices "uninfluenced" by special events.

FSCs are known to offer different classes of fares in à la carte fashion, each being associated with different options and restrictions. The retrieved ticket prices were the cheapest options and, like those of the LCC's, the quoted prices were for non-changeable and non-refundable tickets. We thus a priori assumed that ticket price plays an important role in air travellers' decisions. For routes served by more than one flight per day (FSC only) we chose the cheapest option among all flights, having in mind targeted leisure segment. On the LCC websites, we added the price of one extra piece of checked baggage to even the ticket class settings.
The data have been obtained for a number of routes with FSC and LCC competition (such as London, Paris, Brussels, etc.) and for routes with FSC service only (such as Amsterdam, Berlin, Rome, etc..). It should be noted that we also collected fares for routes served by LCC only (such as Dortmund, Basel, Eindhoven), for the sake of pricing dynamics comparison (vs. LCC pricing on routes with competition). By competition, we refer to routes between two cities served by at least two carriers, one FSC and one LCC. It should be noted that for some city pairs different airports are served. We identified a set of routes which both allows for a meaningful statistical analysis and keeps the demanding data collection process manageable, bearing as well in mind the route length criterion, as discussed later in the text. Due to low LCC flight frequency, the decision was made to also collect FSC ticket prices on the days preceding (D-1) and following (D+1) the 'competing' day, to check if the prices at D- 1 and D+1 significantly differ. Namely, since there is no LCC competition on these days, FSC might tend to offer tickets at increased prices.

Data, i.e. the cheapest available tickets for a route on a given day, were collected in the evening hours in the same time intervals, as it has been claimed that booking hours matter in this respect [6]. The data was collected from one computer with dynamic IP, with cache and cookies cleaned before each query; allegedly, repeating queries from one IP and without cleaning cache and cookies may affect price. As a small test, we performed multiple consecutive queries for the same tickets without changing IP address and cleaning cache and cookies.

The prices obtained from three different websites were always the same for the same routes; however, we received three warnings for increased number of queries from the same "internet location". Similar preventive mechanisms have already been reported in the literature [7].

In total, we collected 3000 unique ticket prices for 21 different routes. After pre-processing the data we ended up with a balanced panel. Ticket prices were converted to Euros using officially published daily middle exchange rates (the National Bank of Serbia). We used only prices data for the initial analyses, since the data necessary for the second stage analysis (discriminants) are still being collected.

\section{DATA ANALYSIS AND RESULTS}

Ticket prices are grouped based on carrier type (FSC or LCC), type of route (presence of competition or not) and the day of flight for competing routes (presence of competition on the day or not). After grouping, average prices are calculated per each group. 
Table 1 summarizes key ticket prices descriptive statistics and is complemented with Figure 1 and Figure 2.

It can be seen from Table 1 that, on routes with competition, average ticket prices are some $10 \%$ lower on the day when both FSC and LCC operate, compared to days when there are only FSC flights (i.e. on previous and following day). Qualitatively similar situation, albeit with smaller differences between D and $\mathrm{D} \pm 1$ prices, is found on routes with FSC service only.

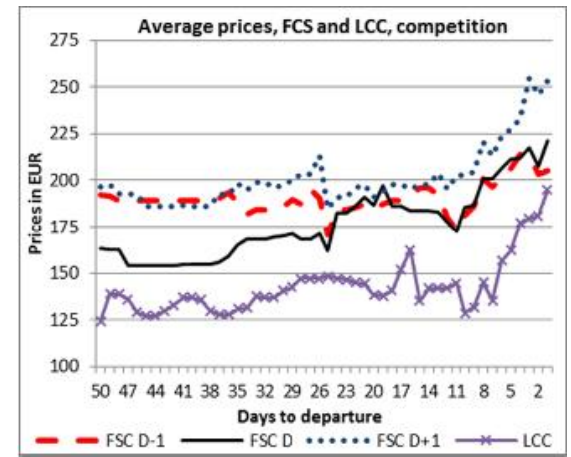

Figure 1 - Average ticket prices, FSC and LCC, compet

Figure 1 shows temporal evolution of average lowest prices for FSC and LCC for routes with competition. Solid lines denote FSC lowest (without markers) and LCC lowest (with markers) prices on the day when both FSC and LCC operate on a route. Ticket prices on those same routes when FSC operate only and face no LCC competition (due to low frequency of LCC flights) are shown in a dashed line for flights on the day before and in a dotted line for flights on the day after. Up to 25 days before departure, average prices on the day when both FSC and LCC operate are well below average prices on the days with no LCC flights on a route (Figure 1). This might suggest that presence of an LCC competitor on a route on a given day exerts a downward effect on fares charged by FCS for that day. LCC prices are constantly well below the FSC ones, yet they seem to follow a fairly similar temporal pattern, only with a slight lag.

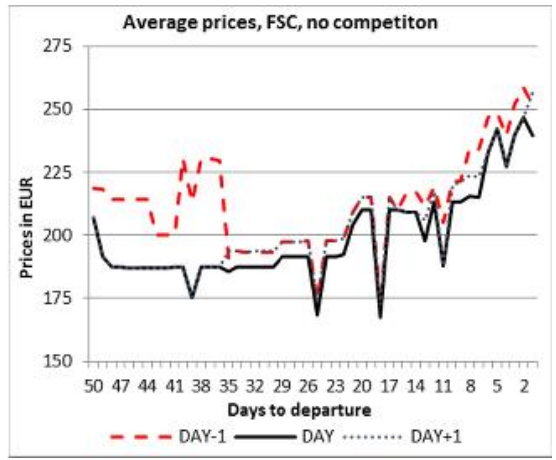

Figure 2 - Average ticket prices, FSC, no competition
On routes where FSC operate only (Figure 2), prices are almost the same for all three days (except for the first two weeks, when prices for flights one day before are higher), unlike the case where FSCs compete with LCCs. This finding in a way reinforces the case for noticeable impact of LCC presence on a route on prices posted by FSC.

Table 1. Average ticket prices per group, in Euros

\begin{tabular}{|c|c|c|c|c|c|}
\hline $\begin{array}{l}\text { Carrier, } \\
\text { Competition, Day }\end{array}$ & Median & Mean & St.dev & Min & Max \\
\hline FSC, $C^{*}, D-1^{* *}$ & 189 & 190 & 8.3 & 171 & 214 \\
\hline FSC, C, D** & 171 & 177 & 19.0 & 154 & 221 \\
\hline $\mathrm{FSC}, \mathrm{C}, \mathrm{D}+1^{* *}$ & 197 & 201 & 16.6 & 185 & 254 \\
\hline FSC, NC* ${ }^{*}, \mathrm{D}-1$ & 174 & 174 & 11.3 & 148 & 202 \\
\hline FSC, NC, D & 164 & 166 & 10.9 & 145 & 194 \\
\hline FSC, NC, D+1 & 167 & 168 & 11.5 & 148 & 199 \\
\hline LCC, C & 138 & 142 & 14.7 & 124 & 195 \\
\hline
\end{tabular}

${ }^{*} \mathrm{C}$ - Competition, $\mathrm{NC}$ - No competition

**D-1 - Day before, D - Flight departure, D+1 - Day after.

Since prices are not normally distributed, we turn to nonparametric tests, i.e. Friedman's ANOVA rank test [8], followed by pair-wise Wilcoxon sign-rank test [9].

The Friedman's test shows statistically significant difference between ticket prices depending on the presence or absence of competition (LCC) on FSC routes $\left(\chi^{2}(2)=59.186, p=0.000\right)$. Post-hoc Wilcoxon test, with a Bonferroni correction applied $(p<$ 0.017 ), reveals that median prices are lower on the day when FSC and LCC compete on a route, compared to days without competition $\left(Z^{C, D-1}=-4.591\right.$, $p^{C, D-1}=0.000$ for $\mathrm{D}-1$ and $Z^{C, D+1}=-6.145$, $p^{C, D+1}=0.000$ for $\left.\mathrm{D}+1\right)$.

Interestingly, similar results are observed also for FSC routes with no competition, i.e. prices for quoted day are lower than prices on the day before $\left(Z^{N C, D-1}=-5.759, p^{N C, D-1}=0.000\right)$ and after $\left(Z^{N C, D+1}=-3.978, p^{N C, D+1}=0.000\right)$. Since we don't control for various days of week (Tuesdays and Wednesdays included only), we cannot state with certainty if these days tend to be generally "cheaper" compared to other days of the week or it is due to airlines' pricing policy.

Even though the routes are of similar length, bearing in mind that route length could be a good proxy for airline's cost [10], we then normalize the data with distances (Great Circle distances between two airports) to compare prices on routes with and without competition. Mann-Whitney test [11] showed that FSC prices on routes with competition are lower (mean ranks) compared to FSC prices on routes without 
competition on the same day $(U=35.500, p=$ 0.000).

To observe the dynamics of price changes we first observe percentage changes in ticket prices time series, followed by volatility analysis. If we plot percentage changes of prices over time, we can see that LCC tend to change prices (Figure 3) more frequently than FSC (Figure 4). Toward departure day these changes intensify, with prices increasing most of the time (positive percentage change). FSC change prices less frequently than LCC. Due to several FSC promotions on a number of routes, there are few deeps followed by seemingly "outlying" increase of prices (Figure 4). It is also interesting to notice that the FSC average prices decrease on the day prior to departure (Figure 4). Similar pattern of price changes is observed for equivalent FSC and LCC price changes on non-competing routes.

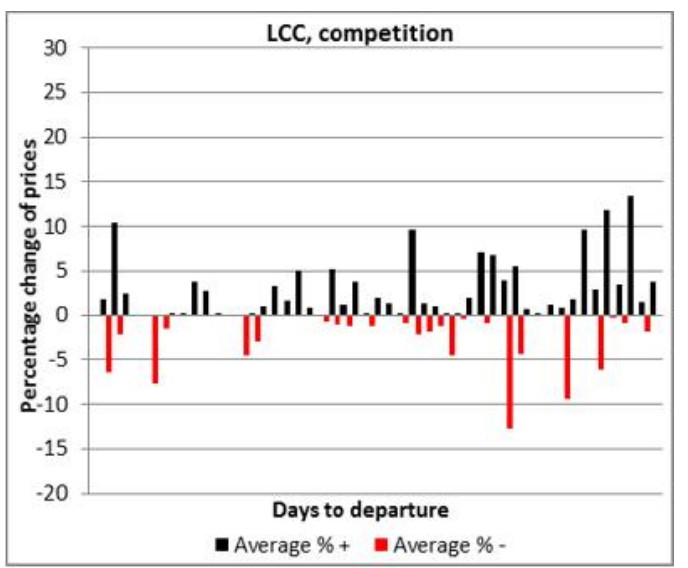

Figure 3 - Price changes, LCC, competition

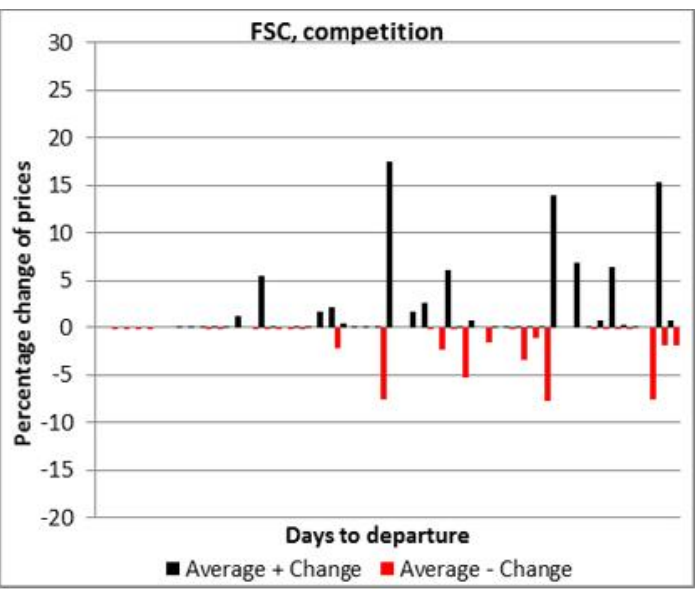

Figure 4 - Price changes, FSC, competition

Due to moderate sample size we further observe price changes in time through simple measure of volatility, as defined in [12]:

$$
V_{i, t}=\alpha V_{i, t+1}+(1-\alpha)\left(\frac{P_{i, t}}{P_{i, t+1}}-1\right)^{2}
$$

where,
$V_{i, t}$ - is the price volatility for route $i, t$ days before departure $\left(V_{i, 50}=0\right)$,

$P_{i, t}-$ is the lowest fare on that route (we observe LCC and FSC separately) and

$\alpha$ - is a smoothing constant which is used for adjusting weights of recent vs distant price changes.

We choose $\alpha=0.8$ as suggested by [13], which gives more weight to more recent changes, compared to distant ones. The prices are normalized in (1), so it is possible to compare FSC and LCC volatility on the same scale.

As the departure date approaches, volatility for both FSC and LCC increases (in line with findings in [14]), with FSC having more volatile prices on routes with no competition (Figure 6). Again, this is mainly due to few FSC promotions on some routes. In the last two to three weeks volatility is mostly driven by the increase in prices, with few FSC volatility peaks being driven by the decrease of prices. Overall level of price volatility is lower on routes with competition, as depicted in Figure 5. Furthermore, volatility does not increase as rapidly as in "no competition" case.

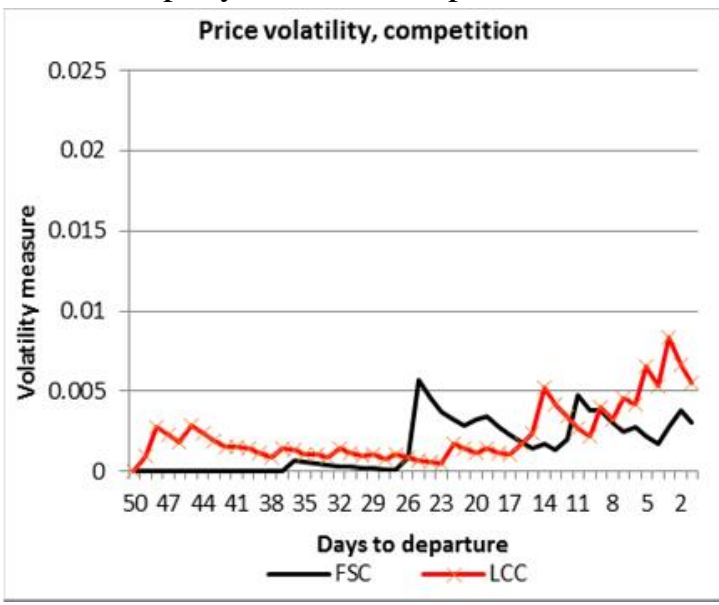

Figure 5 - Price volatility FSC and LCC, competition

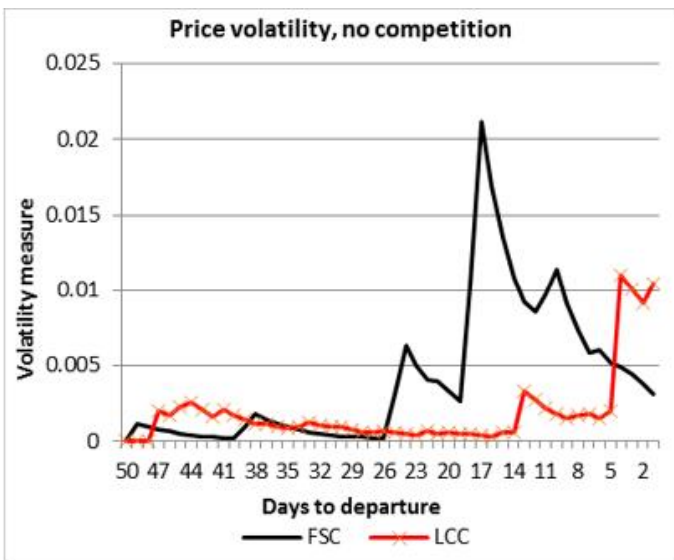

Figure 6 - Price volatility FSC and LCC, no competition 
Lastly, we check if there was a 'correlation' between ticket prices of a given airline on a given route on different dates (with and without competition). To do so, we use Granger causality test [15]. The results suggest that on routes with competition there is no causality between FSC D and D+1 prices, while on the other hand FSC D-1 prices Granger-cause D prices $\left(\chi^{2}(2)=9.949530, \mathrm{p}=0.0069\right)$. On routes without competition, FSC D prices Granger-causes D-1 $\left(\chi^{2}(2)=9.223057, \mathrm{p}=0.0099\right)$, but not vice versa. Granger causality test revealed no correlation in D to $\mathrm{D}+1$ prices in any direction.

Due to the modest data sample, we decided to use Vector Auto Regressive (VAR) model as a robust model to explore the relationship (linear dependencies) between FSC and LCC prices [16]. A simple case of bivariate VAR model with two variables (FSC and $L C C$ are price time series), with current values depending on only one previous value (lag 1) can be written as:

$$
F S C_{t}=\beta_{10}+\beta_{11} F S C_{t-1}+\alpha_{12} L C C_{t-1}+e_{1 t},
$$

$L C C_{t}=\beta_{20}+\beta_{21} L C C_{t-1}+\alpha_{21} F S C_{t-1}+e_{2 t}$,

where,

$$
\begin{aligned}
& \alpha, \beta-\text { are coefficients to be estimated and } \\
& e-\text { is a white noise term. }
\end{aligned}
$$

To estimate VAR model, the original time series had to be differenced ones to make the series stationary. Akaike Information Criterion (AIC) was used to aid selecting model lag order (AIC suggested using up to 6 lags in the VAR model). VAR model was estimated in EViews 8 (Student version). The model statistics is presented in Table 2, and coefficients and tstatistics in Table 3.

Table 2. VAR model summary statistics

\begin{tabular}{lcc}
\hline \hline & D(FCS $)$ & D(LCC) \\
\hline \hline R-squared & 0.194693 & 0.181326 \\
Adj. R-squared & 0.146853 & 0.132692 \\
Sum sq. resids & 44307.20 & 32145.64 \\
S.E. equation & 14.81022 & 12.61495 \\
F-statistic & 4.069680 & 3.728365 \\
Log likelihood & -877.8602 & -843.3667 \\
Akaike AIC & 8.287072 & 7.966201 \\
Schwarz SC & 8.490878 & 8.170007 \\
Mean dependent & 1.264909 & 1.730129 \\
S.D. dependent & 16.03429 & 13.54561 \\
\hline \hline & & 34728.75 \\
Determinant resid covariance (dof adj.) & 30655.96 \\
Determinant resid covariance & & -1720.681 \\
Log likelihood & & 16.24820 \\
Akaike information criterion & & \\
Schwarz criterion & & \\
\hline \hline
\end{tabular}

For FSC prices, coefficients with significant tstatistics are at lags 1 and 6 for FSC series (5\% significant level), Table 3. For LCC coefficients with significant lags are 1, 3 and 5 for LCC series and lag 6 from FSC series (5\% significant level). Since it is hard to interpret these coefficients, one usual relies on Granger causality test and impulse response to determine "relationships" between variables. Granger causality test shows that LCC prices does not Granger-cause FSC, but it seems that FSC Granger-cause LCC at $10 \%$ significance level $\left(\chi^{2}(2)=11.9105, p=0.0640\right)$.

\section{Table 3. VAR model coefficients}

\begin{tabular}{|c|c|c|}
\hline & $\mathrm{D}(\mathrm{FCS})$ & $\mathrm{D}(\mathrm{LCC})$ \\
\hline \multirow[t]{3}{*}{$\mathrm{D}(\mathrm{FCS}(-1))$} & -0.319662 & -0.030384 \\
\hline & $(0.07096)$ & $(0.06044)$ \\
\hline & {$[-4.50496]$} & {$[-0.50272]$} \\
\hline \multirow[t]{3}{*}{$\mathrm{D}(\mathrm{FCS}(-2))$} & -0.045717 & -0.003478 \\
\hline & $(0.08070)$ & $(0.06874)$ \\
\hline & {$[-0.56649]$} & {$[-0.05060]$} \\
\hline \multirow[t]{3}{*}{$\mathrm{D}(\mathrm{FCS}(-3))$} & -0.105787 & 0.165991 \\
\hline & $(0.08821)$ & $(0.07513)$ \\
\hline & [-1.19928] & [ 2.20927] \\
\hline \multirow[t]{3}{*}{$\mathrm{D}(\mathrm{FCS}(-4))$} & -0.034417 & 0.045785 \\
\hline & $(0.08838)$ & $(0.07528)$ \\
\hline & {$[-0.38942]$} & {$[0.60821]$} \\
\hline \multirow[t]{3}{*}{$\mathrm{D}(\mathrm{FCS}(-5))$} & 0.069984 & 0.096016 \\
\hline & $(0.08810)$ & $(0.07504)$ \\
\hline & [ 0.79439$]$ & [ 1.27956$]$ \\
\hline \multirow[t]{3}{*}{$\mathrm{D}(\mathrm{FCS}(-6))$} & -0.278142 & 0.180377 \\
\hline & $(0.08786)$ & $(0.07484)$ \\
\hline & {$[-3.16561]$} & [ 2.41017] \\
\hline \multirow[t]{3}{*}{$\mathrm{D}(\mathrm{LCC}(-1))$} & -0.053646 & -0.260150 \\
\hline & $(0.08229)$ & $(0.07009)$ \\
\hline & {$[-0.65192]$} & {$[-3.71160]$} \\
\hline \multirow[t]{3}{*}{$\mathrm{D}(\mathrm{LCC}(-2))$} & 0.058994 & 0.002377 \\
\hline & $(0.08352)$ & $(0.07114)$ \\
\hline & [ 0.70633$]$ & {$[0.03342]$} \\
\hline \multirow[t]{3}{*}{$\mathrm{D}(\mathrm{LCC}(-3))$} & -0.028054 & -0.148464 \\
\hline & $(0.08613)$ & $(0.07336)$ \\
\hline & {$[-0.32572]$} & {$[-2.02369]$} \\
\hline \multirow[t]{3}{*}{$\mathrm{D}(\mathrm{LCC}(-4))$} & -0.148701 & -0.111967 \\
\hline & $(0.08601)$ & $(0.07326)$ \\
\hline & {$[-1.72897]$} & {$[-1.52841]$} \\
\hline \multirow[t]{3}{*}{$\mathrm{D}(\mathrm{LCC}(-5))$} & -0.096139 & 0.159586 \\
\hline & $(0.09065)$ & $(0.07721)$ \\
\hline & {$[-1.06058]$} & [ 2.06687] \\
\hline \multirow[t]{3}{*}{$\mathrm{D}(\mathrm{LCC}(-6))$} & 0.052632 & 0.029451 \\
\hline & $(0.08866)$ & $(0.07552)$ \\
\hline & [ 0.59365$]$ & {$[0.39000]$} \\
\hline \multirow[t]{3}{*}{$\mathrm{C}$} & 2.276181 & 1.655198 \\
\hline & (1.08473) & $(0.92395)$ \\
\hline & [ 2.09838] & [ 1.79144$]$ \\
\hline
\end{tabular}

Vector Autoregression Estimates

Standard errors in ( ) \& t-statistics in [ ] 
Impulse response functions (response to Cholesky one standard deviation innovations \pm two standard errors) suggests higher influence of changes in FSC to LCC prices, especially at lag 4 (Figure 7). This result is generally consistent both with VAR model ( $L C C$ equation has significant coefficient with $F S C$ series at lag 6) and Granger causality test, suggesting that FSC prices actually influence $\mathrm{LCC}$ prices.
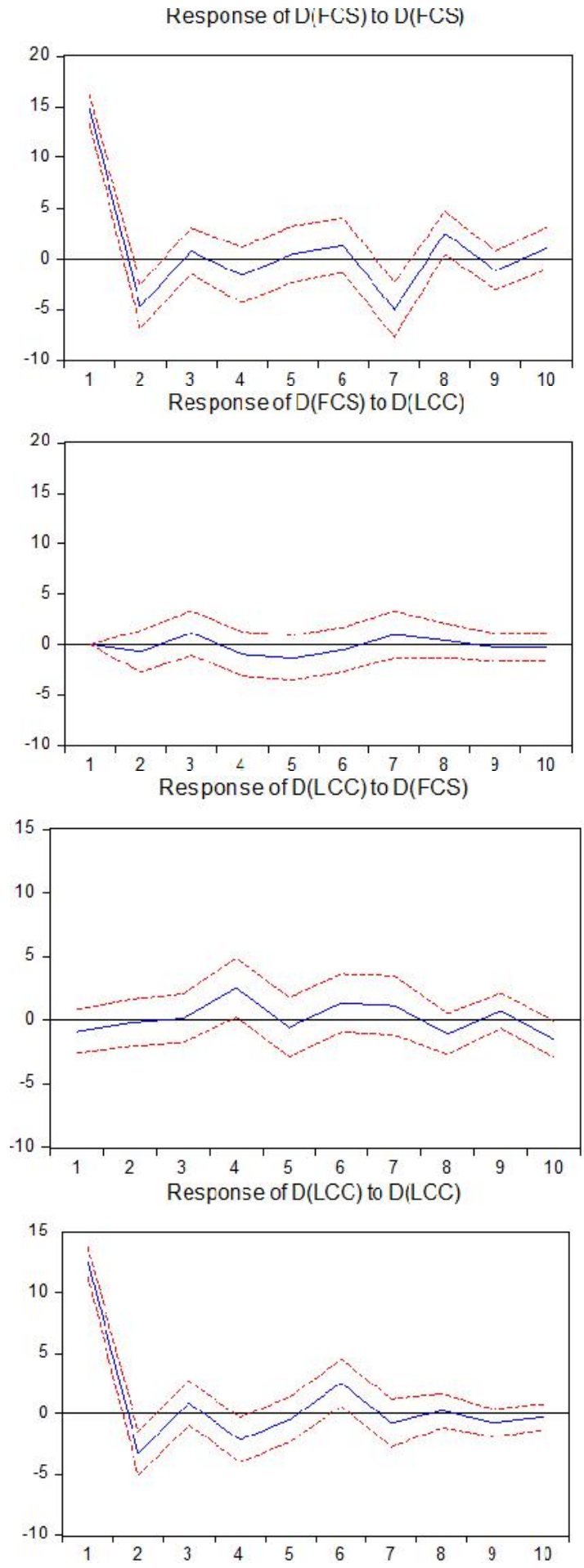

Figure 7 - Impulses response function for VAR model

\section{DISCUSSION AND CONCLUSIONS}

The initial analysis conducted in this research has yielded some interesting results. Most notably, our findings tend to suggest that the presence of LCC route competition indeed affects the pricing behaviour of FSC operating from Belgrade Nikola Tesla Airport (BEG). This relates chiefly to significantly lower FSC fares for days when both FSC and LCC operate between same city pairs, compared to days when LCC competitors do not fly. In addition, some Grangercausality was identified between fares set by FSC and LCC, suggesting that LCCs tend to observe and react to the fares set by FCS on same routes, but not vice versa. There are at least a couple of possible explanations - some generic, and some case-specific - for this finding.

The generic one relates to inherent differences in business models between LCCs and FSCs, reflected, inter alia, in substantially different cost structures and, partly as a consequence thereof, notably different revenue management (pricing) practices. The other possible explanation might be the preferential treatment of the key FSC at BEG, in terms of airport charges [17] which arguably puts more pressure on LCCs to compensate for this difference by more responsive pricing of the basic product sold - the airfare. However, one might also argue that an effectively preferential treatment concerning airport charges is also a very well-known feature of LCC business model [18], so it might be that some of the LCCs considered actually exercise the (qualitatively) same advantage on the other end of some of the routes from our sample.

It should not be forgotten that the results shown in this paper reflect supply-side considerations only. Clearly, including demand-related explanatory variables might significantly impact the results of the analysis. Furthermore, airport (and air navigation) charges are incorporated in analysed prices, which additionally blurred the desired airline competition effects (since the comparison includes fares as perceived by a potential traveller, thus including airport charges too).

For instance, we have recently witnessed a significant cut in frequencies of an LCC (Wizz Air) from BEG due to the already mentioned new airport incentive scheme which discontinued the support to that LCC backing, instead, the national carrier (Air Serbia) [19].To take some of these factors into account, along with increasing the sample size, are some of the first next steps to be taken in our further research efforts.

\section{ACKNOWLEDGMENTS}

This research was conducted with the support from Project TR36033, research grant of the Ministry of 
Science and Technological Development of the Republic of Serbia.

\section{REFERENCES}

[1] Yeoman I, McMahon-Beattie U. Revenue management: a practical pricing perspective, Palgrave Macmillian, 2010.

[2] Chen M, Chen ZL. Recent Developments in Dynamic Pricing Research: Multiple Products, Competition, and Limited Demand Information, Production and Operations Management, Vol. 24, No. 5, pp. 704-731, 2015.

[3] Piga CAA, Bachis E. Pricing Strategies by European Traditional and Low Cost Airlines: Or, When is it the Best Time to Book on Line?, in: Lee D. (ed.), Advances in Airline Economics. The Economics of Airline Institutions, Operations and Marketing, Elsevier, 2007.

[4] Alderighi M, Cento A, Piga CA. A case study of pricing strategies in European airline markets: The London - Amsterdam route, Jorunal of Air Transport Management, Vol. 17, No. 6, pp. 369-373, 2011.

[5] Eurocontrol, Statistics and forecasts (STATFOR) | Eurocontrol [Internet]. [Cited: 10.06.2014] Available at: http://www.eurocontrol.int/statfor

[6] Escobari D, Rupp N, Meskey J. Dynamic price discrimination in airlines [Internet]. SSRN; 2013 [Cited: 08.06.2014]. Available at: http://papers.ssrn.com/sol3/papers.cfm?abstract_id= 2248124

[7] McAfee PR, Te Velde V. Dynamic pricing in the airline industry, In: Hendershott TJ (Ed.), Handbook on Economics and Information Systems, vol. 1. Elsevier Handbooks in Information Systems, Bingley, UK:Emerald Group Publishing Ltd., 2007.

[8] Mack GA, Skillings JH. A Friedman-type rank test for main effects in a two-factor ANOVA, Journal of the American Statistical Association, Vol. 75, No. 372, pp. 947-951, 1980.
[9] Wilcoxon F, Katti SK., Wilcox RA. Critical values and probability levels for the Wilcoxon rank sum test and the Wilcoxon signed rank test, American Cyanamid Comp, 1963.

[10]Swan WM, Adler N. Aircraft trip cost parameters: A function of stage length and seat capacity, Transportation Research Part E: Logistics and Transportation Review, Vol. 42, No. 2, pp. 105-115, 2006.

[11]Lehmann EL. Nonparametrics: Statistical Methods Based on Ranks, McGraw-Hill, San Francisco, 1985.

[12]Gillen D, Mantin B. Price volatility in the airline markets, Transportation Research Part E: Logistics and Transportation Review, Vol. 45, No. 5, pp. 693 709, 2009.

[13]Han S, Gupta S, Lehmann DR. Consumer price sensitivity and price thresholds, Journal of Retailing, Vol. 77, No. 4, pp. 435-456, 2001.

[14]Smith MD, Bailey JP, Brynjolfsson E. Understanding digital markets : review and assessment, Cambridge, MIT Press, 1999.

[15]Granger CWJ. Some recent development in a concept of causality, Journal of Econometrics, Vol. 39, No. 1-2, pp. 199-211, 1988.

[16]Brooks C. Introductory Econometrics for Finance, Cambridge University Press, 2014.

[17]Službeni glasnik. Zaključak o usvajanju smernica razvoja vazduhoplovnog tržišta kroz stimulacije u plaćanju aerodromskih naknada u Republici Srbiji. Službeni glasnik Republike Srbije 119/2013, 2013.

[18]Barbot C. Low-cost airlines, secondary airports, and state aid: An economic assessment of the RyanairCharleroi Airport agreement, Journal of Air Transport Management, Vol. 12, No. 4, pp. 197-203, 2006.

[19]Wizz Air. Wizz Air halves Belgrade fleet after airport becomes too expensive [Internet]. 2014 [Cited: 10Apr-2014]. Available at: https://wizzair.com/enGB/about_us/news/wizen239 


\section{REZIME}

\section{UVID U DINAMIKU CENA AVIO-KARATA NA TRŽIŠTIMA U RAZVOJU: EFEKTI PRISUSTVA NISKOTARIFNIH PREVOZNIKA NA LINIJAMA SA AERODROMA „NIKOLA TESLA“ U BEOGRADU}

Dinamika cena i upravljanje prihodima avio-kompanija su predmet istraživanja već duže od dvadeset godina. Oslanjajući se na bogatu literaturu, u ovom radu se analizira vremenska komponenta opaženih obrazaca tarifiranja na tržištima u razvoju. Poseban fokus u radu zauzima analiza potencijalnog uticaja ulaksa niskotarifnih avio-kompanija na tržište na cenovnu politiku tradicionalnih avio-kompanija već prisutnih na Aerodromu „Nikola Tesla“ Beograd. Za razliku od prethodnih istraživanja, u ovom radu se analizira tržište koje karakteriše relativno niska frekvencija letova, koji su uglavnom na kraćim $i$ srednje dugim rutama. Analiza dinamike cena je izvršena za letove na rutama koje opslužuju samo tradicionalne avio-kompanije, kao i na rutama na kojima tradicionalne avio-kompanije imaju konkurenciju u niskotarifnim avio-kompanijama. U radu su procenjeni efekti konkurencije na rutama na cenu karata.

Ključne reči: dinamika cena, konkurencija avio-kompanija, tržište u razvoju 